leadership, new social relationships, alternative scientific methods, and innovative strategies. We would argue that in the complex modern social world of public health, a better understanding of the philosophical foundations of the professional orientation of the public health expert may help in making the right choices. This editorial is meant to be an invitation to reflective philosophical discussion about these foundations.

HARRY G J NIJHUIS

LAURENT J G VAN DER MAESEN

1 Parsons T. The structure of social action: a study in social theory with special reference to a group of recent European writers. Glencoe: The Free Press,

2 Merton R. Social theory and social structure. Glencoe: The Free Press, 1949.

3 Homans GG. The human group. 4th ed. London: Routledge \& Kegan Paul, 1964.
4 Henderson LJ. In: Barber B, ed. On the social system: selected writings. Chicago: University of Chicago Press, 1970.

5 Frankenberg R. Your time or mine?: an anthropologic view of the tragic temporal contradictions of biomedical practice? Int $\mathfrak{f}$ Health Serv 1988;1:11-35.

6 Bhaskar R. The possibility of naturalism: a philosophical critique of the contemporary human sciences. Sussex: The Harvester Press, 1979.

7 Vanberg V. Die Zwei Sociologien: Individualismus und Kollektivismus in de Sozialtheorie. Tübingen: JCB Mohr, 1975.

8 Backett $\mathrm{K}$, Currie C, Hunt S, et al. Changing the public health. Chichester: RUHBC/University of Edinburgh, John Wiley \& Sons, 1989.

9 WHO, Health and Welfare, Canada. Canadian Public Health Association, Ottawa charter for health promotion: an international conference on health promotion: towards a new public health. Ottawa: WHO, Health and Wealfare, 1986.

10 Foucault M. Naissance de la clinique. Une archéologie du regard médical. Paris: Presses Universitaires de France, 1963.

1 Feyerabend P. Against method. Norfolk: Thetford Press, 1975.

12 Habermas J. Theorie des kommunikatieven Handelns, Band 1 und 2. Frankfurt am Main: Surhkamp Verlag, 1981.

13 Renton A. Epidemiology and causation: a realist view. $f$ Epidemiol Community Health 1994;48:78-84.

\section{Key words and indices}

From the first issue in 1994 there will be a change in the method of indexing the subjects of the Fournal of Epidemiology and Community Health and the author index will no longer include the title of the paper, becoming a list of authors only. Papers will be indexed by a keyword system, and authors will be asked to choose up to three keywords for each paper at manuscript stage. A keyword is a word (or phrase) which will identify the subject matter of a written paper in an index. The keywords selected will be entered by the typesetters and formed into an index at the printers. The index will be published, as usual, at the end of each volume in December. The format will be different, with the title of the paper repeated after each keyword on every entry.

On the surface, choosing index headings may not seem difficult but authors will soon realise that epidemiology has many synonyms, near-equivalent descriptions, use of adjectives as descriptors, assorted lay terms, and also Latin words and syndromes which complicate the picture. Examples of this can be seen in different terminology used in case-control or case-referent studies; whether the words prospective and retrospective are used or excluded; whether diseases are described as relating to the heart or cardiovascular or circulatory system or are cardiac; and whether for communicable diseases the common names or proper names of infectious agents are used.

An index should be consistent. It is not good if half the entries are under "Passive smoking" and half under "Smoking, passive". Further difficulties can arise because authors will not know what other work is being published, or under what titles, in the same volume. The keyword will be chosen at the earliest stage of publication not at the latest as it is now. When using the new index users are therefore advised to look under all possible headings each time.

Authors are advised to scan papers for headings that may not be in the title, and to avoid general terms such as epidemiology, cancer, and heart disease. In general, it is better not to split accepted concepts. For instance, it is better to use "Health promotion" as a keyword, rather than "Promotion, health".

Only a few shortened forms can be accepted. AIDS and HIV are universally known, but mostly the full form should be used as the keyword. There will be no cross references in the keyword index.

This cannot be more than an attempt to guide authors and perhaps to warn of the pitfalls, but it is important to remember that if authors wish to have their work found easily in the index they should consider the keywords carefully. 